\title{
2021 Handbook of Florida Water Regulation: State Groundwater Discharge Regulations ${ }^{1}$
}

\author{
Michael T. Olexa, Tatiana Borisova, and Jana Caracciolo²
}

\section{Preface}

This handbook is designed to provide an accurate, current, and authoritative summary of the principal federal and state (Florida) laws that directly or indirectly relate to agriculture. This handbook provides a basic overview of the many rights and responsibilities that farmers and farmland owners have under both federal and state laws as well as the appropriate contact information to obtain more detailed information. However, the reader should be aware that because the laws, administrative rulings, and court decisions on which this handbook is based are subject to constant revision, portions of this publication could become outdated at any time. Several details of cited laws are also left out due to space limitations. This handbook is provided as an educational text for those interested in water use and water resource issues in Florida.

This handbook is distributed with the understanding that the authors are not engaged in rendering legal or other professional advice, and the information contained herein should not be regarded as a substitute for professional advice. This handbook is not all inclusive in providing information to achieve compliance with the federal and state laws and regulations governing water protection. For these reasons, the use of these materials by any person constitutes an agreement to hold harmless the authors, the UF/IFAS Center for Agricultural and Natural Resource Law, and UF/IFAS Extension for any liability claims, damages, or expenses that may be incurred by any person as a result of reference to or reliance on the information contained in this handbook. Note: UF/IFAS is the acronym for University of Florida, Institute of Food and Agricultural Sciences.

\section{Florida's Groundwater}

Florida has several prolific aquifers important for groundwater availability in wells, as well as water flow in springs, lakes, and rivers. Groundwater is an important water source for agricultural irrigation. Furthermore, approximately ninety percent of Floridians rely on aquifers as a source of drinking water (USGS 2020). Protection of the quality of groundwater is of critical importance.

Aquifers can be confined (shielded by a layer of lower permeability, such as clay) or unconfined. Unconfined aquifers always require more protection because they are more susceptible to contamination than confined aquifers. Aquifer water quality also requires special protection in the regions where they are the primary source of drinking water.

For more information about Florida water resources, see FE757 (Florida's Water Resources).

1. This document is FE601, one of a series of the Food and Resource Economics Department, UF/IFAS Extension. Original publication date October 1998. Revised June 2017 and April 2021. Visit the EDIS website at https://edis.ifas.ufl.edu for the currently supported version of this publication.

2. Michael T. Olexa, professor, Food and Resource Economics Department, and director, UF/IFAS Center for Agricultural and Natural Resource Law; Tatiana Borisova, associate professor, Food and Resource Economics Department; and Jana Caracciolo, student, Levin College of Law; UF/IFAS Extension Gainesville, FL 32611.

The Institute of Food and Agricultural Sciences (IFAS) is an Equal Opportunity Institution authorized to provide research, educational information and other services

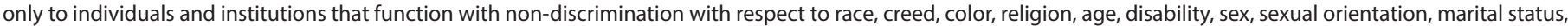

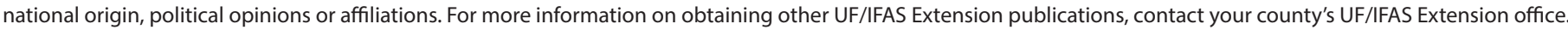
U.S. Department of Agriculture, UF/IFAS Extension Service, University of Florida, IFAS, Florida A \& M University Cooperative Extension Program, and Boards of County Commissioners Cooperating. Nick T. Place, dean for UF/IFAS Extension. 


\section{How does Florida regulate discharges into groundwater?}

Discharge of waste into state waters (including groundwater) is prohibited, unless a permit for discharge is issued by a state agency. A permit will not be issued if the discharge reduces ground or surface water quality below the required Florida Department of Environmental Protection (FDEP) standards (see below).

Note that the application of chemicals to control insects and aquatic weeds for agricultural purposes is exempt from the regulation of discharges into groundwater. This exemption applies only to the chemicals approved for the particular use by the United States Environmental Protection Agency (EPA) or the Florida Department of Agriculture and Consumer Services (FDACS). Furthermore, the chemical applications must be made according to the label and state standards (all the other requirements of the Florida Pesticide Law [Part One, Chapter 487, Florida Statutes] must also be followed).

\section{What are the state groundwater classifications?}

The permits to discharge into groundwater are based on whether the discharge can impact the quality of receiving water. The groundwater quality criteria depend on the designated use of groundwater, and aquifers that provide drinking water are protected with the strictest water quality criteria. By law, groundwater is classified into five designated use categories (Classes G-I, F-I, G-II, G-III, G-IV) based on three criteria: potable vs non-potable water use (i.e., high quality and can be used to supply drinking water), the total of dissolved solids the water contains, and confined versus unconfined aquifer as defined by Florida Administrative Code 62-520.410(1). Under the classification scheme,

1. Class G-I water is groundwater designated to potable water use. This category is groundwater in a "single source" aquifer, implying that the aquifer is the only reasonably available source of potable water to a significant segment of the population. To receive G-I designated use, groundwater should have a total dissolved solids content of less than $3,000 \mathrm{mg} / \mathrm{L}$.

2. Class F-I water is also groundwater in a "single source" aquifer designated for potable water use, with a total dissolved solids content of less than $3,000 \mathrm{mg} / \mathrm{L}$. Surficial aquifers (i.e., shallow aquifers that are close to the surface) in northeast Flagler County are specifically designated as Class F-I water by Florida Administrative Code 62-520.460.

3. Class G-II water is groundwater designated for potable use. For this category, total dissolved solids content should be up to $10,000 \mathrm{mg} / \mathrm{L}$.

4. Class G-III water is groundwater designated for nonpotable use and located in unconfined aquifers with a total dissolved solids content of $10,000 \mathrm{mg} / \mathrm{L}$ or greater.

5. Class G-IV water is groundwater designated for nonpotable use and located in confined aquifers with a total dissolved solids content of $10,000 \mathrm{mg} / \mathrm{L}$ or greater.

Class G-I and F-I waters are the most protected and they have the strictest water quality criteria, while Class G-IV water has the least stringent water quality criteria.

\section{Florida Groundwater Quality Criteria}

The primary groundwater quality criteria are tailored to the designated uses of the groundwater. Minimum criteria requires that all groundwater must not be contaminated by carcinogenic or toxic substance discharges, substances harmful to plants and animals, components that pose a serious danger to public health and welfare, and substances that constitute or create nuisance. Class G-IV groundwater is generally exempt from this requirement unless there is a danger to the environment or to public health, safety, or welfare.

Since in many areas, groundwater is designated as a potable water source, drinking water quality standards can apply to groundwater. For Classes F-I, G-I, and G-II, maximum contaminant levels (primary drinking water standards) are generally in accord with standards developed in the Florida Safe Drinking Water Act. Primary drinking water quality standards are mainly related to health issues, and secondary drinking water quality standards regulate the "aesthetics" of water quality and are not always required. Examples of secondary standards include regulations of water taste and color. 
Permits for the discharge of wastes are not issued under Chapter 403, Florida Statutes, Section 403.088, when maximum containment levels in groundwater are exceeded by a discharge activity unless there is a granted exception.

\section{What are the regulations for water discharges?}

Under Chapter 403, Florida Statutes, Section 403.087, discharge permits (also known as operation permits) are required for stationary installations (i.e., structures that may emit water contaminants in quantities prohibited by the rules). For surface water, federal National Pollutant Discharge Elimination System (NPDES) permits are required if an entity wants to discharge a contaminant into the water. NPDES permits will be issued only when an applicant can establish that the activity or installation in question will not degrade receiving waters below applicable standards.

Note that agricultural water management systems are not required to obtain discharge permits. Essentially, as long as the water in an agricultural management system remains within that particular system (e.g., an irrigation operation), no permit is required. Once the water leaves that particular system, that discharge is then regulated, and the farming activity may be liable for groundwater pollution. To be released from the liability, farmers need to implement applicable Best Management Practices (BMPs) as part of the program administered by the Florida Department of Agriculture and Consumer Services (FDACS). The BMP implementation (supported by recordkeeping and implementation verification visits by FDACS staff) provides a presumption of compliance with state water quality standards. In other words, if an agricultural operation participates in and follows the requirements of the FDACS-administered BMP program, FDEP cannot institute proceedings against the owner of the source of pollution to recover costs or damages associated with the contamination of water caused by the pollutant (see Florida Administrative Code 5M-8.003, Presumption of Compliance). To participate in the FDACS-administered BMP program, agricultural operation must submit the "Notice of Intent to Implement" (NOI) BMPs identified as applicable by FDACS staff during a site visit. For specific information about the BMP program, visit the FDACS website (https://www.fdacs.gov/Agriculture-Industry/ Water/Agricultural-Best-Management-Practices).

\section{What Florida programs address groundwater quality?}

Statewide groundwater quality is addressed in several programs. The Florida Department of Environmental Protection's Division of Resource Management implements two key programs: the Aquifer Protection ProgramUnderground Injection Control, and the Source \& Drinking Water Program.

The Aquifer Protection Program-Underground Injection Control is responsible for implementation of the federal Underground Injection Control (UIC) program. The program issues the permits for the underground injections of the appropriately treated fluids and ensures that Florida's underground sources of drinking water are protected.

The Source \& Drinking Water Program focuses on regulation of public water supply systems, many of which rely on groundwater as a water supply system. Wellhead Protection Programs is an important component of the Source \& Drinking Water Program, focused on protection of the area surrounding a public water well.

In turn, The Florida Department of Environmental Protection's Division of Environmental Assessment and Restoration focuses on water quality monitoring, assessment, and respiration activities. Many of these activities are implemented in recognition of the close link between the quality of ground water and surface water (such as lakes, rivers, or canals). Programs implemented by the Division determines the sources of water quality impairments and assists with identifying actions to restore the quality. Much of the work focuses on springs, including monitoring the water quality in springs, assessing the major sources of nitrogen pollution loading impacting springs, establishing the pollution loading limits (referred to as Total Maximum Daily Load, or TMDL), and evaluating agricultural best management practices to reduce nitrogen loading. Other responsibilities include assisting with the development of Florida's Integrated Water Quality Assessment Report, and evaluating the potential impact of new pesticides on groundwater. To learn more, visit the FDEP website (https://floridadep.gov/springs/protect-restore).

Authority to assist with the implementation and support of these programs is provided by Florida Administrative Code Chapter:

- Chapter 62-520 Ground Water Classes, Standards and Exemptions

- Chapter 62-521 Wellhead Protection

- Chapter 62-524 New Potable Water Well Permitting in Delineated Areas 
- Chapter 62-528 Underground Injection Control

- Chapter 62-531 Water Well Contractors

- Chapter 62-532 Water Well Permitting and Construction Requirements

For more information on the Groundwater Management Program and the Aquifer Protection Program, see FDEP's website: http://www.dep.state.fl.us/water/groundwater/ index.htm.

\section{Sources}

Chapter 487, Florida Statutes, Sections 487.011 to 487.175

Chapter 403, Florida Statutes, Section 403.087

Chapter 373, Florida Statutes, Sections 373.019 to 373.0698

Florida Administrative Code 62-520.410

Florida Administrative Code 62-670

Florida Administrative Code 5M-8.003

Florida Groundwater Program, http://www.dep.state.fl.us/ water/groundwater/index.htm

Florida Water Withdrawals, https://pubs.er.usgs.gov/ publication/sir20195147

\section{Acknowledgments}

The authors are indebted to the personnel of both state and federal agencies who provided their time and advice in the preparation of this handbook. We acknowledge Carol Fountain and Susan Gildersleeve at the University of Florida for their assistance in editing this handbook. We also acknowledge funding received for updating this publication from the James S. and Dorothy F. Wershow Agricultural Law Endowment. 